\title{
Promissory Fraud Without Breach
}

\author{
Gregory Klass \\ Georgetown University Law Center, gmk9@law.georgetown.edu \\ Ian Ayres \\ Yale Law School
}

Copyright 2005 by The Board of Regents of the University of Wisconsin System; Reprinted by permission of the Wisconsin Law Review. Permitted use is limited to the work described above and does not include the right to grant to others permission to photocopy or otherwise reproduce this material except for copies permitted under the Copyright Act.

This paper can be downloaded free of charge from:

https://scholarship.law.georgetown.edu/facpub/123

2004 Wis. L. Rev. 507-533 (2004)

This open-access article is brought to you by the Georgetown Law Library. Posted with permission of the author. Follow this and additional works at: https://scholarship.law.georgetown.edu/facpub

Part of the Contracts Commons 


\section{GEORGETOWN LAW Faculty Publications}

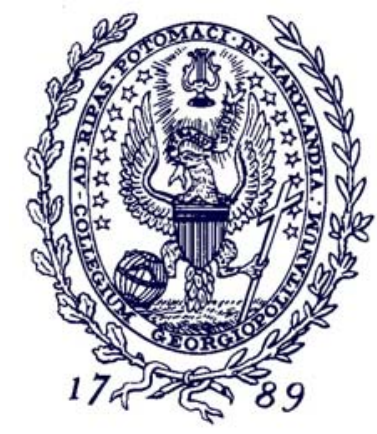

January 2010

\section{Promissory Fraud Without Breach*}

2004 Wis. L. Rev. 507-533 (2004)

\section{Gregory Klass}

Professor of Law

Georgetown University Law Center gmk9@law.georgetown.edu
Ian Ayres

Professor of Law Yale Law School ian.ayres@yale.edu

This paper can be downloaded without charge from:

Scholarly Commons: http://scholarship.law.georgetown.edu/facpub/123/

Posted with permission of the author

*Copyright 2005 by The Board of Regents of the University of Wisconsin System; Reprinted by permission of the Wisconsin Law Review. 


\title{
PROMISSORY FRAUD WITHOUT BREACH
}

\author{
IAN AYRES* \& GREGORY KLASS ${ }^{* *}$
}

\section{INTRODUCTION}

It is no doubt wrong to conflate promise breaking and lying. What parent has not heard a child say with no small degree of indignation, "You lied to me; you promised you would ...." Accusations of this kind can be evidence of conceptual confusion: You might be a scoundrel for breaking your promise, but you are not thereby a liarsomeone who knowingly misrepresents an existing fact. The act of promising to do, or to refrain from doing, something in the future does not, by itself, give the promisor even the opportunity to lie.'

But the action for promissory fraud suggests that our impulse to call certain promise-breakers "liars" is often correct. Promising is a single act with multiple meanings. According to the literal meaning, the speaker of the words "I promise to . .." puts herself under a certain obligation-an obligation to do the act promised. In many contexts, however, a promise to do something also represents an intent to do it. And as Lord Bowen stated in an early promissory fraud case, "the state of a man's mind is as much a fact as the state of his digestion." 2 By saying something about the promisor's present intent, the act of promising creates the opportunity to lie.

We call this category of falsehoods "promissory misrepresentations" or "insincere promises." 3 The idea is a familiar one in literature and popular culture. Consider the following episode

* Townsend Professor, Yale Law School, ian.ayres@yale.edu.

** Assistant Solicitor General, Office of the New York Attorney General, gregory.klass@aya.yale.edu. The views expressed in this Article do not represent those of the Office of the New York Attorney General. The authors would like to thank Sydney Foster and Kevin Reid for truly excellent research assistance.

1. Charles Fried analyzes the mistake of viewing a broken promise as a type of lie in the first chapter of Contract as Promise. See Charles FrIED, CONTRACT AS Promise: A Theory of CONTRaCtual Obligation 9-10 (1981) [hereinafter Contract AS PROMISE].

2. Edgington v. Fitzmaurice, 29 Ch. D. 459,483 (1885).

3. They are also sometimes referred to as "lying promises." See, e.g., T.M. Scanlon, Promises and Contracts, in THE THEORY OF CONTRACT: NEW EsSAYS 86, 8893 (Peter Benson ed., 2001). The term "lying promise" is most often used in connection with Kant's question, "may I, when hard pressed, make a promise with the iutention not to keep it?" Immanuel Kant, Groundwork of the Metaphysics of MORALS 15 (Mary Gregor trans., 1998). It is not obvious, however, that Kant's negative answer to this question rests on the fact that such a promise is a lie and thus "lying promise" may not be the most perspicacious way to characterize Kant's example. In order to avoid invoking Kant or provoking Kant aficionados, we generally eschew the term. 
involving a frog and the king's daughter from the Grimms' version of The Frog Prince:

"[Y]our clothes, your pearls and jewels, and your golden crown [are not for me]," the frog replied. "But if you will love me, and let me be your companion and playmate, and let me sit beside you at the table, eat from your little golden plate, drink out of your cup, and sleep in your little bed-if you promise me all that, l'll dive down and retrieve your golden ball."

"Oh yes," she said. "I'll promise you anything you want, if only you'll bring back the ball." However, she thought, What nonsense the stupid frog talks! He just sits in the water croaking with the rest of the frogs. How can he expect a human being to accept him as a companion."

Or recall Atlas, who, intending to be rid of his burden forever, misled Hercules by promising that if only Hercules would hold up the sky for a little while he would then take it back. Hercules subsequently deceived Atlas into performing his promise by playing the same trick on him. ${ }^{5}$ And in The Producers, Mel Brooks's character knowingly sells more than one-thousand percent of the interest in Springtime for Hitler-clear evidence that he deceived his investors about the chance that each would receive a full return should the show make a profit. ${ }^{6}$

The doctrine of promissory fraud aims to punish such insincere promisors. If a court finds that a defendant-promisor did not intend at the time of promising to perform her promise, then the court can subject her to both compensatory and punitive damages under the doctrine of

4. The Frog Prince, or Iron Heinrich, in The Complete fairy Tales of THE BROTHERS GRIMM 2-3 (Jack D. Zipes trans., 1992).

5. Edith Hamilton, Mrthology 233 (1932).

6. THE Producers (MGM/UA Studios 1968). Once you start looking, examples appear wherever you look in literature. Penelope was lying to the suitors when, during Odysseus's long absence, she promised to announce her choice among them after she finished weaving the funeral canopy for her father, though every evening she undid the work of the previous day. HOMER, THE ODYSSEY 91-109 (Rodney Merrill trans., 2002). And do not forget Homer's description of Autolykos, Odysseus's grandfather, who surpassed "all men in thieving and sly oath taking." Id. at 340. Nor after so many broken promises to hold the ball for Charlie Brown do we think that Lucy ever really intended to allow him to kick it. And finally, as one of our children pointed out, in Jurassic Park III, the Kirbys never intended to keep their promise to fund Dr. Grant's research in exchange for an aerial tour of Isla Sorna, but meant all along to use the opportunity to rescue their teenage son, Eric, who was stranded on the treacherous island after a paragliding mishap. JURASSIC PARK III (Universal Pictures 2001). 
promissory fraud or even sentence her to prison under the corresponding crime of false promise. ${ }^{7}$

But this doctrine is both underdeveloped and undertheorized. ${ }^{8}$ This Article, in keeping with the theme of this Symposium, explores the possibility of promissory fraud liability where there is no breach of contract. It is well known that mere breach of contract is not sufficient to make out a claim of promissory fraud. This rule makes eminent sense, for a promisor who initially intended to perform may have later changed her mind. Here we pose the converse question: is it possible to have promissory fraud liability without a breach? ? $^{9}$

It can look like breach is a necessary element of promissory fraud. And it is true that in most cases a civil action for promissory fraud will occur only where the promisor has failed to perform. This follows from the requirement of the generic action for deceit that the claimant suffer damages as the proximate result of the alleged misrepresentation. ${ }^{10}$ Representations about a promisor's intent are typically material just because the promisee can use them to predict whether or not she will perform. If the promisor performs or has not yet broken her promise, then any damages the claimant suffers are not

7. In order to avoid confusion, we use feminine personal pronouns to refer to promisors and masculine personal pronouns to refer to promisees.

8. See generally IAN Ayres \& Gregory Klass, Insincere Promises: The LAW OF MISREPRESENTED INTENT (forthcoming 2005) [hereinafter INSINCERE PROMISES] (examining this doctrine in greater detail).

9. Keeton covered some of the same ground we do, though he came to some different conclusions. W. Page Keeton, Fraud-Statements of Intention, 15 TEx. L. REV. 185, I98-2 I6 (1937).

The drafters of the Restatement (First) of Contracts assumed that a contract had to be enforceable in order to give rise to an action for promissory fraud:

Though a promise that could in no event be binding, or a mere prediction, may involve the same representation of mental attitude as if the promise were made for sufficient consideration, the representation is not fraud unless there is implied . . . an assertion of other facts. One who is informed as to the law would not be deceived, and the consequences of ignorance of the law are here, as generally, not sufficient basis on which to found Iegal relief.

Restatement (First) of Contracts $\S 473 \mathrm{cmt}$. d (1932). For examples of this doctrine in action, see Louis R. Frumer, Recent Cases, Fraud-Misrepresentation of Intention-Promise Unenforceable as Such, I6 TEX. L. REv. 407, 407-08 (1938); and Joe Robert Greenhill, Recent Cases, Fraud-Promissory Representations-Parol Evidence Rule, 16 TEX. L. REV. 408, 408-I0 (1938).

The Restatement (Second) of Contracts has rejected this view, though it does not articulate a theory as to when an unenforceable promise can be an actionable misrepresentation of intent. RESTATEMENT (SECOND) OF CONTRACTS $\$ 171(2)$ (1981). The Restatement (Second) of Torts states that a claim for promissory fraud is actionable "whether or not the promise is enforceable as a contract." RESTATEMENT (SECOND) OF TORTS $\S 530 \mathrm{cmt}$. c (1977).

10. See, e.g., W. Page Keeton et al., Prosser and Keeton on torts $\S 105$, at 728 (5th ed. 1984) [hereinafter Prosser AND KeETON]. 
the proximate result of the promisor's misrepresentation, and there is no action for promissory fraud. ${ }^{11}$

This argument, while correct as far as it goes, is not enough to show that breach is a necessary element of promissory fraud. There are two reasons why this is the case. First, and more obvious, not every broken promise gives rise to an action for breach of contract. No action might arise because of a formal defect (for example, violation of the Statute of Frauds or lack of consideration), because the broken promise is illusory, because the parties have expressly opted-out of legal enforceability, or because performance is illegal or enforcement is against public policy.

These rules raise the question of whether there can be an action for promissory fraud absent enforcement in contract. Our conclusion is that in many-but not all-situations, promissory fraud liability is appropriate even though a breach-of-contract remedy is not available. Whether liability is appropriate depends, not surprisingly, on the rationale for nonenforcement. In fact, allowing for promissory fraud liability can support the suspension of contractual liability. Freedom from contract is all the more palatable when the most egregious caseswhere the promisor never intended to perform-are still subject to liability under promissory fraud.

Second, and less obvious, the victim of a promissory misrepresentation can suffer proximate harm even in the absence of nonperformance. And this harm is not limited to the indignity of being duped. In many option settings, a misrepresented intent may give rise to an action for promissory fraud even where the defendant has not broken any promise. Why this is so turns on the difference between not intending to perform and intending not to perform. Explicating this relatively subtle distinction-which courts almost always overlook-puts

11. The court in Brabham v. American National Bank of Union Springs used similar logic to reject a lender's claim that a bank failed to perform its promise to setlle an unpaid loan. 689 So. $2 d 82,87$ (Ala. Civ. App. 1996). The promise required the lender to provide payment in certified funds, which he had failed to do

[b]ecause the [claimant] never properly accepted the bank's offer, [andl the bank was under no obligation to perform. 1t appears, therefore, that any damage the [claimant] may have suffered resulted from their failure to accept properly the bank's settlement offer, rather than from any fraud on the bank's part. Accordingly, the [claimant] could not have produced substantial evidence of Id. proximate cause in their claim of promissory fraud.

Nonperformance is clearly not necessary in criminal prosecution of false promise, where there is no proximate cause requirement. See United States v. Mucci, 630 F.2d 737, 741 (10th Cir. 1980) (finding that the defendant had not yet breached was no defense because "in the face of evidence that the contract was fraudulent from the beginning, there being no intent to perform and no intent to return the money, and that this was known to [the defendant]"). 
us on the road to a more nuanced understanding of what a promise can say about the promisor's intent.

We address these two points in reverse order.

\section{PROMISSORY FRAUD WITH PERFORMANCE}

We can get at the idea that a promisor might be liable for promissory fraud even though she has not broken a promise by way of the following example. Suppose Leona enters into an express option contract with Donald whereby she agrees that within a year she will either buy Donald's land for $\$ 100,000$ or pay him $\$ 5000 . .^{12}$ By entering into this take-or-pay contract, Leona has not expressed an intention to buy the land. The whole point of such an option contract is to allow Leona to induce a certain amount of reliance on Donald's part (for example, he will not sell the property to someone else) without committing herself to buy.

But what if Leona enters into the take-or-pay contract with an affirmative intention not to buy the land? Suppose she is building a shopping mall on a neighboring site and only wants the option to keep Donald from selling the property to a competitor who has announced plans to build his own mall but will not be able to compete if Leona has a one-year head start. There is a strong intuition that Leona has misled Donald. Whilc the purchasing of an option does not say that the purchaser intends to exercise it, in many cases it does represent that the purchaser does not intend not to do so. And this representation is highly material. Because Donald believes that there is a fair chance that Leona will within the next year buy the property for $\$ 100,000$, he charges her less for the option than he would if he were simply agreeing not to sell it for a year. And when at year's end Leona realizes her initial intent not to exercise her option, Donald has suffered a proximate harm. He has kept the property off the market for a year-perhaps losing forever his opportunity to sell to Leona's competitor. We think that if Donald can prove Leona's initial intent in court, then he should be able to recover for her promissory misrepresentation, even though Leona has not broken any promise.

12. Contracts of this type are readily found in the real world and are generically referred to as "take or pay" or "alternative performance" contracts. Publishers routinely promise authors to either publish a book and pay $X$ or not publish and pay $x$ (where $X$ is greater than $x$ ); oil companies promise landholders either to drill on their land and pay $Y$ or not drill and pay $y$. Twentieth Century Fox famously promised Shirley MacLaine that it would either use her in the film Bloomer Girl and pay her ten percent of the gross profits plus expenses or not use her and pay her only $\$ 750,000$. See Parker v. Twentieth Century-Fox Film Corp., 474 P.2d 689, 690 (Cal. 1970); Victor P. Goldberg, Bloomer Girl Revisited or How to Frame an Unmade Picture, 1998 Wis. L. REv. 1051,1054 \& n.7. 
Now examples like this may seem confined to the relatively unique context of option contracts, where one course of performance-not exercising the option-looks like a sort of nonperformance. But the tale of Leona and Donald raises interesting issues about imposing promissory fraud liability in non-option contracts or contracts for performance.

To begin with, the story demonstrates the error of thinking of promisor intent in terms of a binary choice between intent to perform and intent not to perform. It is possible not to intend to do something, and at the same time not to intend not to do it. That is, a promisor who does not intend to perform may not intend not to perform. ${ }^{13}$ She may instead have a conditional intent (to perform if such-and-such is the case) or a disjunctive intent (for example, to perform or pay damages). Or she might simply have no attitude with respect to the act promised, for example because she misunderstood the objective meaning of her promise and intends to do $y$, though she promised to do $x$.

Once we have this analytic distinction in view, we can also see the possibility of alternative interpretive regimes. The law might instead stipulate that a promise, like an option contract, does not represent an intent to perform, though it still says something about what the promisor intends-namely, that she does not intend not to perform. In fact, something like this might be taken to follow from Oliver Wendell Holmes's famous statement that "[t]he duty to keep a contract at common law means a prediction that you must pay damages if you do not keep it[]-and nothing else." ${ }^{14}$ If we believe Holmes, then every contractual promise is no more than a take-or-pay contract, giving the promisor the option to perform or pay damages. And if this is so, why think a legally enforceable promise represents an intent to performrather than an intent to perform or pay damages?

Now we doubt whether this approach is correct, either as a matter of everyday semantics or of best legal practices. ${ }^{15}$ For one thing, it

13. Courts generally do not readily recognize the difference. See 37 AM. JUR. 2D Fraud and Deceit $\S 90$, at 123-24 (2001). We are aware of only three opinions that discuss the difference between not having an intention to do something and intending not to do it. See Bissett v. Ply-Gem Indus., Inc., 533 F.2d 142, 145 (5th Cir. 1976); Home Seekers' Realty Co. v. Menear, 135 So. 402, 402-03 (Fla. 1931); Bauer v. Adams, 550 S.W.2d 850, 853-54 (Mo. Ct. App. 1977). In Bissett v. Ply-Gem Industries, Inc., the court remarked that "a promise is actionable as fraud only when the promisor had a positive intent not to perform his promise, or made the promise without a present intent to perform it." 553 F.2d at 145 .

14. Oliver W. Holmes, The Path of the Law, 10 Harv. L. Rev. 461, 462 (1897).

15. We also doubt whether this is a sound reading of Oliver Wendell Holmes's views. Holmes's statement that a contractual duty is a prediction that one must perform or pay damages probably was formulated with an eye more to dramatic impact than to precision. Elsewhere, Holmes makes it clear that he does not view a legally binding 
does not conform to our intuitions about everyday promissory practicewhether the context bc a pcrsonal and extra-legal promise or an armslength transaction. For another, we think that there are good reasons why promisors want to implicitly say that they intend to perform simpliciter, rather than that they intend to perform or pay damages, or that they do not intend not to perform, or nothing at all about their intent. Promisees care about promisor intent because they care deeply about whether or not the promisor will perform. If a promisee thinks that the promisor does not intend to perform and is seriously considering the option of paying damages instead, then he is much less likely to rely on her promise, be it by entering into a binding contract or by otherwise ordering his behavior as if performance were going to happen. But the whole point of promising is to convince others to rely on one's future actions. ${ }^{16}$ Thus promisors have a natural incentive to

promise as a promise to perform or to pay damages. For instance, Holmes writes in The Common Law: "the statement that the effect of a contract is the assumption of the risk of a future event does not mean that there is a second subsidiary promise to assume that risk, but that the assumption follows as a consequence direcily enforced by the law, without the promisor's co-operation." O.W. HOLmeS, JR., THE COMmON LAW 302 (1881). Similarly, in a letter to Sir Frederick Pollock from December 11, 1928, Holmes takes issue with:

the impression that 1 say that a man promises either $\mathrm{X}$ or to pay damages. I don't think a man promises to pay damages in contract any more than in tort. He commits an act that makes him liable for them if a certain event does not come to pass, just as his act in tort makes him liable simpliciter.

2 Holmes-Pollock Letters: The Correspondence of Mr. Justice Holmes and Sir FrederiCK POLLoCK 1874-1932, at 233 (Mark D. Howe ed., 1941); see also 1 HolmesPOLLOCK LETTERS, supra, at 177; Joseph M. Perillo, Misreading Oliver Wendell Holmes on Efficient Breach and Tortious Interference, 68 ForDHAM L. REv. 1085, 1085-91 (2000).

16. This aspect of promising is most emphasized by those who want to assimilate contractual obligations to tort-like obligations. Patrick Atiyah, for instance, writes: "people who make promises very often-perhaps usually-do so because they want to get something from the promisee which they can only get by doing so .... [P]romises are given to induce people to act upon them." PATrick ATIYAH, Promises, Morals AND the LAW 143-44 (1981). But it is recognized even by those who prioritize the moral dimension. Thus Fried explains the desirability of the practice of promising as follows:

By [making nonoptional a course of conduct that would otherwise be optional for mel I can facilitate the projects of others, because I can make it possible for those others to count on my future conduct, and thus those others can pursue more intricate, more far reaching projects. If it is my purpose, my will that others be able to count on me in the pursuit of their endeavor, it is essential that $I$ be able to deliver myself into their hands more firmly than were they simply to predict my future conduct ....

... We need a device to permit a trade over time: to allow me to do A for you when you need it, in the confident belief that you will do B for me when I need it.

FRIED, supra note 1, at 13. 
communicate with their promisees an intent to perform. This fact explains why most promises represent an intent to perform and why the law should adopt a default interpretation that recognizes this fact.

That said, the above discussion reveals the possibility that in some contexts a promise may not say that the promisor intends to perform, but, like the purchase of an option, only that the promisor does not intend not to perform. Thus, a law school applicant who has not yet heard from her first-choice school but pays a nonrefundable deposit to her safety school does not misrepresent her intent to enroll, because her promise does not say that she presently intends to attend. Similarly, it is commonly understood that making a retail mail-order purchase does not represent a present intent to keep the product, as evidenced by the fact that many retailers include a return shipping label. But nor do these promises say nothing about the promisor's intent. We think that paying a nonrefundable tuition deposit or making a mail-order purchase represents at least that the applicant does not intend not to attend or that the customer does not intend not to keep the goods. The option example shows not only that in some contexts a promise does not represent an intention to perform, but also that such a promisor may still be liable for promissory fraud if she affirmatively intends not to perform.

We can draw three conclusions from our discussion of promissory fraud liability with performance. First, it is wrong to assume that every promise automatically represents an intent to perform. In some contexts, a promise may say much less than this. Second, it is equally wrong to assume that where a promise does not represent an intent to perform, it says nothing about the promisor's intent. It may still say, for example, that the promisor does not intend not to perform. Third, the point of saying something about promisor intent is to communicate something about the probability of performance. At least one of the reasons promises represent an intent to perform is that promisors want to convince promisees to rely on their performing. While there is more to say about what promises do and do not indicate about promisor intent and the probability of performance, ${ }^{17}$ these observations provide the necessary distinctions for understanding promissory fraud in the absence of a legally enforceable promise.

\section{PROMisSORY Fraud Without BREACH}

In addition to importing punitive damages into contract law, the action for promissory fraud can expand legal liability in situations where a plaintiff would otherwise not have an action for breach. We examine

17. See InSINCERE PROMISES, supra note 8 , ch. 2,5 . 
eight contexts where nonperformance does not give rise to an action for breach: precontractual negotiations; representations that are found to be mere puff; violations of the Statute of Frauds or the parol evidence rule; lack of consideration; illusory promises; agreements with TINALEA clauses; illegal promises; and procreative and political promises. Our conclusion is that there is no one-size-fits-all answer to the question of whether promissory fraud liability is appropriate in the absence of legal enforceability, but that in many situations freedom from contract should not entail freedom from legal responsibility for promissory misrepresentations.

\section{A. Preformation Promises}

Much ink has been spilled over the question of whether contractlike liability should attach in precontractual negotiations. At least since Hoffman v. Red Owl Stores, Inc. ${ }^{18}$ in 1965 , some courts have applied promissory estoppel on the basis of gratuitous promises or assurances that one will make or accept a future offer. The arguments for and against such liability are by now well-rehearsed. ${ }^{19}$ We sympathize with the position that precontractual liability is desirable in some contexts. Here, however, we want to argue that even if the law does not impose contract-like duties on negotiating parties, it should hold them liable for their precontractual misrepresentations of intent. In fact, imposing liability for such misrepresentations can prevent the most egregious and injurious precontractual misdeeds, thereby making all the more palatable the idea of freeing the parties from Red Owl-type liability.

Ironically enough, Red $O w l$ itself provides an object lesson in how such liability might operate. In Red Owl, the Wisconsin Supreme Court considered the case of a prospective franchisee-Hoffman-who was induced to comply with what turned into a series of increasingly onerous franchise conditions. ${ }^{20}$ As countless law students have read:

The record here discloses a number of promises and assurances given to Hoffman ... upon which [the Hoffmans] relied and acted upon to their detriment.

Foremost were the promises that for the sum of $\$ 18,000$ Red Owl would establish Hoffman in a store. After Hoffman

18. 26 Wis. 2 d 683, 133 N.W.2d 267 (1965).

19. See generally E. Allan Farnsworth, Precontractual Liability and Preliminary Agreements: Fair Dealing and Failed Negotiations, 87 COLUM. L. REV. 217 (1987); Jason Scott Johnston, Communication and Courtship: Cheap Talk Economics and the Law of Contract Formation, 85 VA. L. REv. 385 (1999).

20. 26 Wis. $2 d$ at $696-97,133$ N.W.2d at 274. 
had sold his grocery store and paid the $\$ 1,000$ on the Chilton lot, the $\$ 18,000$ figure was changed to $\$ 24,100$. Then in November, 1961, Hoffman was assured that if the $\$ 24,100$ figure were increased by $\$ 2,000$ the deal would go through. Hoffman was induced to sell his grocery store fixtures and inventory in June, 1961, on the promise that he would be in his new store by fall. In November, plaintiffs sold their bakery building on the urging of defendants and on the assurance that this was the last step necessary to have the deal with Red Owl go through. ${ }^{21}$

This series of subsequently unfulfilled assurances suggests that Red Owl Stores may not have intended to grant a franchise for the initial amount quoted, or at least that Red Owl Stores recklessly misrepresented the probability that it would do so. Repeated assurances without performance can be evidence both of lack of intent (the doctrine of chances) and of a low probability of performance (scientific induction). Indeed, the smell of promissory fraud-or at least of negligent promissory misrepresentation-emanating from these facts might be an important factor in explaining both why the Red Owl court was willing to impose precontractual liability ${ }^{22}$ and why other courts have generally failed to follow the invitation to extend promissory estoppel to failed negotiations.

There is no reason to countenance such deceptive negotiating behavior. As the facts in Red $O w l$ show, engaging in precontractual negotiations can be costly-not only in time invested, but also in lost opportunities to contract with other parties and good faith preparatory investments that, in the event of a contract, will benefit both parties. And there is a strong intuition that the very act of negotiating implicitly represents at least that you do not intend not to enter into a contractthat you are not stringing the other party along. In some contexts, like where the other party can be expected to incur significant negotiation costs, it may even represent that you affirmatively intend to contract. ${ }^{23}$

21. Id.

22. Id. at 701-02,133 N.W.2d at 276-77.

23. The parties can explicitly opt out of such representations. Consider the following problem posed to Randy Cohen's ethics column in the New York Times Magazine: "Telemarketers offered us a free weekend at a fabulous ski resort if we attend a one-hour sales presentation. I'd love to go, but my husband thinks it would be unethical since we have absolutely no intention of purchasing a time share." Randy Cohen, The Ethicist, N.Y. Times, Nov. 5, 2000, § 6, at 22. Such offers typically come with a "no purchase required" clause, which we think is enough to defeat the default representation of an intent to consider the offer. In fact, because the parties have explicitly opted out of contract-type damages, we should allow there to be no representation of intent at all. See discussion infra note 61 . 
These representations, whether they are implicit or explicit, create value because they enable parties to stay on the road to mutually beneficial contracts. The law should therefore back them up by imposing liability when they are false. And when such misrepresentations are made knowingly or recklessly, punitive damages are appropriate.

Precontractual promissory fraud liability is not limited to Red Owltype situations. These issues are also raised in what are referred to as "bait and switch," or often simply "bait" advertisements. The Federal Trade Commission Guides Against Bait Advertising define the bait and switch practice in classic promissory fraud terms:

Bait advertising is an alluring but insincere offer to sell a product or service which the advertiser in truth does not intend or want to sell. Its purpose is to switch consumers from buying the advertised merchandise, in order to sell something else, usually at a higher price or on a basis more advantageous to the advertiser. ${ }^{24}$

Some state legislatures have declared bait advertising to be a crime, but only subject violators to rather mild misdemeanor sanctions. ${ }^{25}$ As one treatise opines: "[n]either the law of contracts nor ordinary judicial remedies have been of great help to the unwary consumer who is persuaded to make the switch." ${ }^{26}$ The logic of promissory fraud provides to our minds a way of providing protection that may now be lacking.

\section{B. Mere Puff?}

Where a representation is found to be mere puff, it does not give rise to an action for breach of contract. In most cases, there should also be no action for promissory fraud.

A statement is mere puff when it is objectively unreasonable to rely on it. Though it has the form of a statement of fact or of a promise, it is better understood as an encouragement or exhortation. In most cases, this fact also means that the puff says nothing as to the speaker's intentions or the probability of her performance-not even that she does not intend not to perform. There is therefore no basis for a claim of promissory fraud.

24. 16 C.F.R. $\S 238.0$ (2003) (emphasis added).

25. See Wade R. Habeeb, Validity, Construction and Effect of State Legislation Regulating or Controlling "Bait-and-Switch" or "Disparagement" Advertising or Sales Practices, 50 A.L.R.3D 1008, 1010-11 (1973).

26. Richard E. SPeidel \& Ian Ayres, Studies in CONTRact Law 252 (6th ed. 2003). 
As an example, consider Leonard v. Pepsico, Inc., where the plaintiff took the defendant beverage company up on its advertised "offer" that it was possible to buy a Harrier Jet with a sufficient number of "Pepsi points"-points that, it turned out, could be accumulated for a fraction of the jet's market value. ${ }^{27}$ As the district court noted when it rejected the plaintiff's breach of contract claim, the ad had an outlandish, joking quality ${ }^{28}$ Unlike cases where a binding offer is found, the ad nowhere intimated that Pepsi meant the "offer" to be taken seriously. ${ }^{29}$ Consequently, we would also not condemn Pepsi if it admitted that it intended not to perform this promise..$^{30}$

More difficult evidentiary questions arise when a speaker makes what could be construed as an offer for a unilateral contract, but argues that it was intended as mere puff. Consider the old chestnut, Carlill $v$. Carbolic Smoke Ball Company. ${ }^{31}$ Here the seller famously promised:

$100 £$ reward will be paid by the Carbolic Smoke Ball Company to any person who contracts the increasing epidemic influenza, colds, or any disease caused by taking cold, after having used the ball three times daily for two weeks according to the printed directions supplied with each ball. $1000 \mathbb{f}$ is deposited with the Alliance Bank, Regent Street, shewing our sincerity in the matter. ${ }^{32}$

The court found that this language sufficed to create a contractual obligation. ${ }^{33}$

27. 88 F. Supp. 2d 116, 118-21 (S.D.N.Y. 1999), aff'd, 210 F.3d 88, 89 (2d Cir. 2000) (per curiam).

28. Id. at 132.

29. Id. at 119-21.

30. A number of cases have rejected promissory fraud claims on similar grounds. See, e.g., Shirley v. Cmty. Bank, 690 So. 2d 421, 424 (Ala. Civ. App. 1997) (determining that loan officer's assurances that approval was likely was mere enthusiasm, not promise); Bulbman, Inc. v. Nevada Bell, 825 P.2d 588, 589, 592 (Nev. 1992) (per curiam) (determining that representation that telephone installation would take thirty minutes and that there would be no problems was mere puffery); Dowling $\mathbf{v}$. NADW Mktg., Inc., 625 S.W.2d 392, 395 (Tex. Ct. App. 1981) (determining that a statement in newspaper ad of a "Firm Buy Back Agreement" was mere dealer's talk and not a promise); Stone v. Enstam, 541 S.W.2d 473, 481 (Tex. Civ. App. 1976) (determining that overly optimistic predictions cannot be the basis for promissory fraud action). But see Joe E. Manuel \& Stuart F. James, Tennessee's Theories of Misrepresentation, 22 MEM. ST. U. L. REV. 633, 650 (1992) ("The practical effect of promissory misrepresentation may be that, in some instances, typical sales talk and puffery is elevated to a level of actionable misrepresentation.").

31. [18931 1 Q.B. 256 (C.A. 1892).

32. Ild. at 257 (quotations omitted).

33. Id. at 263 . 
From our perspective, if the plaintiff could show the company did not intend to pay this reward to unhealthy users, then it should also be subject to a claim for promissory fraud. And there is evidence that this was so. Carbolic Smoke Ball argued to the court that the advertisement was a mere puff and that any agreement was a nudum pactum. ${ }^{34}$ Given these positions, one can imagine the court finding that the company intended not to perform because the company did not believe that it was making an offer capable of legal acceptance; a promise supported by consideration.

Now we have some reservations about taking a promisor's in-court interpretation of the scope of her promise as conclusive evidence of her intentions. In doing so, one runs the risk of deterring defendants from legitimately arguing an alternative interpretation of the contract ("What I meant was . . . .") by threatening to turn that defense against them as evidence of a promissory misrepresentation ("But then you didn't intend...."). And taking such testimony as proof positive of promissory fraud neglects the scienter requirement that should attach to all fraud claims, ${ }^{35}$ since the promisor's alternative erroneous understanding of her promissory act may be a matter of mere negligent or even reasonable mistake, and therefore not deserving of full promissory fraud liability.

In the situation of Carbolic Smoke Ball, however, this use of the defendant's testimony would be warranted, for Carbolic Smoke Ball's proffered interpretation of its promise as a mere puff was facially reckless. The assurance that the $£ 1000$ was on deposit "to show our sincerity" was a clear signal that the offer was not mere puff. ${ }^{36}$ We should worry about deterring defendants from offering alternative reasonable interpretations of their promises, but not about chilling patently unreasonable defenses.

Judge Posner, sitting in the District Court of Illinois, reached a similar conclusion in Price v. Highland Community Bank, ${ }^{37}$ holding that a defendant's testimony "that he never intended to commit himself to set up the promised [employee] incentive-compensation program" was sufficient evidence of an intent not to perform to support a jury's finding of promissory fraud. ${ }^{38}$ Posner suggested that the more plausible explanation of the defendant's nonperformance was that he "intended to establish an incentive program . . . but that he later changed his mind because he was dissatisfied with the performance of the marketing

34. Id. at 261-62.

35. See Prosser and KeEton, supra note $10, \S 105$, at 728.

36. Carbolic Smoke Ball Co., 1 Q.B. at 261 (internal quotations omitted).

37. 722 F. Supp. 454 (N.D. Ill. 1989).

38. Id. at 460 . 
staff." ${ }^{39}$ The defendant, however, chose, in the face of a clearly binding promise ${ }^{40}$ to argue that his statements were mere puff. Once the jury concluded that there was a contractual obligation, the defendant was deservedly hoisted by his own petard, since his admitted lack of intent was, given the clear meaning of his promise, at least reckless. ${ }^{41}$

Between these two extremes-Carbolic Smoke Ball and Highland Community Bank, on the one hand, and Leonard $\nu$. Pepsico, on the other-there are cases in which there is found to be a legally enforceable promise that the promisor reasonably or negligently mistook for mere puff. In these cases, the scienter requirement is not met and no action for promissory fraud should lie, though the promisee might succeed on a claim for negligent misrepresentation or unilateral mistake. Because the promisor in such a case would have a colorable claim of mere puff, we would not want to deter her from making such a defense and would therefore not allow her in-court testimony that she meant only puff to be used as evidence of no initial intent to perform.

\section{The Statute of Frauds and Parol Evidence}

One of the most litigated contexts in which allegations of insincere promising appear is where the Statute of Frauds or the parol evidence rule applies. The reason is obvious: not only is promissory fraud one of the few mechanisms of securing punitive damages for breach, but it is also a way to avoid the preclusive effect of these rules with regard to certain oral promises. Promissory fraud is tailored to prevent the misuse of these rules as tools for deceit. ${ }^{42}$

A central concern in implementing these antifraud doctrines is that opportunistic promisors will manipulate the doctrines to dupe innocent

39. Id. at 459.

40. See id. at 458. When he was seeking to hire the claimant, the defendant stated both orally and in a letter that her pay package would include a profit-sharing element, confirmed after she was hired in a terms and conditions letter which read: "the incentive program outlined in [the earlier letterl goes into effect immediately." Id. (internal quotations omitted).

41. Id. at 459-62. It is worth comparing Posner's opinion in Speakers of Sport, Inc. v. ProServ, Inc., in which the U.S. Court of Appeals for the Seventh Circuit affirmed summary judgment against a promissory fraud claimant in part on the grounds that the alleged promise was in fact mere puff. 178 F.3d 862, 866-68 (7th Cir. 1999).

42. Our conclusions about how promissory fraud can stem from the potential misuse of these rules apply also to other mandatory formal limits on contracting, like the Rule Against Perpetuities, time restrictions on agreements not to compete, and even statutes of limitation. The same arguments also apply to consent-protecting rules like the requirement of a capacity to contract. A minor who is legally unable to enter into a mutually binding contraet should be held liable if she attempts to turn this shield into a sword by entering into such a contract intending to raise the defense of incapacity. See Keeton, supra note 9, at 210-13. 
promisees. A bad actor might orally promise many things that she intends never to perform, precisely because she knows that the parol evidence rule or the Statute of Frauds will later render the promise nugatory:

It could go without saying that these rules are not meant to shield fraud, but they may well have just that effect if they prevent a party from showing that he has been deceived by an oral promise, made to induce reliance and action but without the slightest intention of keeping it. ${ }^{43}$

The doctrine of promissory fraud addresses just such misuses. Opportunistic promisors are deterred by threatening them with punitive damages should their scheme be exposed. ${ }^{44}$

Of course there is the competing concern that opportunistic promisees will use an action for promissory fraud as a way of thwarting the antifraud goals of the Statute of Frauds and parol evidence rule. ${ }^{45}$ The inevitable tension between the need to prevent the promisor's fraud and the need to prevent the promisee's has led some to suggest splitting the difference. A few courts, for instance, allow evidence of fraudulent parol promises only if they do not directly contradict the written agreement. ${ }^{46}$ Others have advocated limiting recovery-for example, to

43. Fleming James, Jr. \& Oscar S. Gray, Misrepresentation-Part II, $37 \mathrm{MD}$. L. REV . 488, 507 (1978) (emphasis added) (footnotes omitted).

44. We are not the first to notice this function of promissory fraud liability. See James \& Gray, supra note 43, at 507-08; Keeton, supra note 9, at 200-09; George N. Stepaniuk, The Statute of Frauds as a Bar to an Action in Tort for Fraud, 53 Fordham L. Rev. 1231, 1240-47 (1985); Evan M. Zuckerman, Note, Promissory Fraud in Tennessee: A Wrong Without a Remedy, 10 MEM. ST. U. L. REV. 308, 332-33 (1980).

Section 209(a)(2) of the Uniform Computer Information Transactions Act (UCITA) captures a similar idea by limiting the waivability of express promises made in mass-market retail advertisements. U.C.I.T.A. §209(a)(2) (2002). For example, it would be fraudulent to run an ad campaign proclaiming a ninety-day right to a refund, while simultaneously crafting a formal mass-market license agreement altering that right. The reasoning behind this rule fits comfortably within our theory.

45. Thus courts have rejected promissory fraud claims based on the principle that "if an action in fraud were allowed to be brought on promises which are unenforceable as contracts, the legislative policy of the [Statute of Frauds] would be defeated." Gen. Corp. v. Gen. Motors Corp., 184 F. Supp. 231, 234 (D. Minn. 1960).

46. See Bank of Am. Nat'l Trust \& Sav. Assoc. v. Pendergrass, 48 P.2d 659, 661-62 (Cal. 1935); see also Justin Sweet, Promissory Fraud and the Parol Evidence Rule, 49 CAL. L. Rev. 877, 889 \& n.73, 896-97 (1961); Margaret C. Johnson, Notes and Comments, Contracts-Fraud-Misrepresentation of State of Mind-Parol Evidence, 17 N.C. L. REv. 32, 35-36 (1938). 
reliance rather than expectation damages, and prohibiting punitive awards-in order to remove the incentive to make a false claim. ${ }^{47}$

We think it unnecessary to split the baby to achieve the proper incentives in these cases. That is, we would simply allow the use of parol evidence to prove promissory fraud, even where such evidence could not be used to prove breach of contract, and allow successful claimants the full range of damages, including punitives. First, the mere possibility of limited compensatory damages may not be enough to deter those who would misuse rules like the Statute of Frauds or the parol evidence rule as tools for deceit. Where wrongdoers think they are unlikely to be caught, only punitive damages will suffice. Second, opportunistic promisees can be thwarted by effective judicial monitoring of the sufficiency of the evidence. The affirmative burden of establishing a promissory misrepresentation-proving the promisor's initial intent-is itself a substantial safeguard against trumped-up contracts. The safeguard is enhanced by prevailing procedural rules such as the heightened pleading requirements for claims of fraud, raising the burden of proof to clear and convincing evidence, and the rule that the mere nonperformance of a contract does not warrant the inference of a wrongful initial intent. Finally, in order to qualify for full-blown punitive damages, a claimant must also show that the misrepresentation was made recklessly or knowingly. ${ }^{48}$ So long as the law of promissory fraud is structured to avoid false-positives, it will not pose a threat to the effective functioning of either the Statute of Frauds or the parol evidence rule.

\section{Lack of Consideration}

Promises that are unenforceable because of lack of consideration might appear to pose a more difficult question. It is hard to imagine a promisor misusing the consideration requirement in the way that the Statute of Frauds or parol evidence rule can be converted into a tool for deceit. What is the incentive for her to do so? A promisor who makes a gratuitous promise knowing that it cannot be enforced has not gained anything thereby because she has not been paid any consideration. ${ }^{49}$

47. See Goldsmith v. Vrooman, 23 S.E.2d 504, 505 (Ga. Ct. App. 1942); Stepaniuk, supra note 44, at 1250. Justin Sweet considers and rejects other possible limitations on recoverable damages as a way of splitting the difference. Sweet, supra note 46 , at $897-903$.

48. Our theory of scienter is more fully adumbrated in chapters three and six of our forthcoming publication. INSINCERE Promises, supra note 8 , chs. 3, 6 .

49. Alternatively, it has been suggested that there can be no action for promissory fraud because, where there is no consideration, there can be no reasonable reliance. Barrier v. Brinkmann, 109 S.W.2d 462, 466-67 (Tex. Comm'n App. 1937); Clarence C. Kunc, Fraud-Misrepresentation of Intent, 19 NEB. L. BULL. 39, 40 (1940). 
But, this is perhaps too narrow a view of what motivates promisors. As an example, recall the facts in Ricketts $v$. Scothorn. ${ }^{50}$ Ricketts had presented his granddaughter a $\$ 2000$ note, so that she would not have to work any more, but died before performing his gratuitous promise. ${ }^{51}$ This representation left the granddaughter, who had quit her job in reliance, to bring an action against his estate for enforcement of the promise..$^{52}$ Now suppose that Ricketts's private letters indicated that he never intended to perform his promise-he was intentionally stringing his granddaughter along simply because he wanted her to quit the job. It seems to us that, at the very least, the granddaughter has been wronged and deserves to be made whole. And why not deter such bad-faith promises with punitive damages?

The above example, however, is merely hypothetical and we have been unable to find any cases where promissory fraud liability lay in the absence of consideration. This suggests that there may be a de facto consideration defense, warranted or not. In fact, Judge Posner has suggested that one of the reasons for Illinois' hostility towards promissory fraud is a fear of "circumventing the limitation that the doctrine of consideration is supposed however ineptly to place on making all promises legally enforceable." 53

Whether one agrees with this approach will depend, in part, on what one thinks of the consideration requirement. We are not going to wade into that doctrinal swamp. But we would emphasize that with the proper procedural safeguards, promissory fraud does not threaten to create an action for breach where none existed before. In addition to showing nonperformance, a promissory-fraud plaintiff must prove: (1) the promisor's intent at the time of promising; (2) that he reasonably relied on the promise; and (3) that he suffered proximate harm from its nonperformance. If the plaintiff hopes to secure punitive damages, then he must also demonstrate (4) that the promisor made the misrepresentation knowingly or recklessly. Because a properly formulated and enforced law of promissory fraud sets a relatively high bar-one that most disappointed promisees have no hope of clearing-it poses no general threat to the doctrine of consideration. Instead, it supports fair dealing and the reliable flow of information. On balance, a claim for promissory fraud should be actionable even though the

50. 77 N.W. 365,366 (Neb. 1898).

51. Id.

52. Id. The Nebraska Supreme Court famously held that the grandfather's promise, while not creating a contract, could support an action for promissory estoppel. Id. at 367.

53. Desnick v. Am. Broad. Co., Inc., 44 F.3d 1345, 1354 (7th Cir. 1995). 
promise lacks consideration-as a potential complement to promissory estoppel liability. ${ }^{54}$

\section{E. Illusory Promises}

An illusory promise is a statement that has the form of a promise, but by its own terms does not put the promisor under any obligation. Though an illusory promise has no binding force qua promise, it should still give rise to potential liability for promissory misrepresentations contained in it.

Consider, for example, the facts underlying Spooner v. Reserve Life Insurance Co. ${ }^{55}$ In this case, the employer's life insurance company issued a bulletin to all of its agents titled "Extra Earnings Agreements." The bulletin stated, "you will receive at the end of each 12 month period a bonus," which was to be based on the percentage of policies agents were able to renew after lapse. ${ }^{57}$ But in a separate paragraph, the company also included the following term: "This renewal bonus is a voluntary contribution on the part of the Company. It is agreed by you and by us that it may be withheld, increased, decreased or discontinued, individually or collectively with or without [actual] notice." 58

A promise that only needs to be performed at the sole discretion of the promisor is illusory and undermines any contractual duty to perform. Unsurprisingly, the Washington Supreme Court rejected the employee's breach-of-contract claim when the insurance company refused to pay the bonus. ${ }^{59}$ But what about liability for promissory fraud?

It is true that an illusory promise, by expressly giving the promisor the choice of not performing, opts out of the normal representation that the promisor intends to perform. In this respect, an illusory promise is like a nonrefundable tuition deposit or a mail-order purchase. Proof

54. A more moderate proposal for protecting the consideration requirement would be a rule that without consideration, there can be no recovery for nonfraudulent promissory misrepresentation. And it is true that it is significantly easier to prove nonfraudulent promissory misrepresentation than it is to show promissory fraud, since the former does not require evidence of scienter. But even establishing nonfraudulent promissory misrepresentation is so difficult that the action poses no real threat to the consideration requirement-think about how hard it is to show reasonable reliance on a gratuitous promise. Therefore, liability for promissory misrepresentation remains appropriate.

55. 287 P. 2 d 735 (Wash. 1955).

56. Id. at 736 (internal quotations omitted).

57. Id. (internal quotations omitted).

58. Id. at 737 (alteration in original).

59. Id. at 738 . 
that Reserve Life did not intend to pay the bonus, but meant to do so only if it were a good year, would not be enough to show promissory fraud.

But, as we emphasized in our discussion of option contracts, it does not follow that Reserve Life's promise said nothing about its intent. Even though illusory, the promise represented at least that Reserve Life did not affirmatively intend not to perform. Just as the developer who buys an option to purchase land should be held liable for misrepresentation if she initially intended not to purchase, the employer who dangles the possibility of a bonus, intending that it will never be paid, should be punished for her duplicity. In fact, the Spooner court, while ruling against the plaintiff-employee, observed that the defendant was "perilously near the perpetration of a fraud." ${ }^{00}$ An illusory promise should give rise to a valid claim for promissory fraud if the promisee can show that, at the time of promising, the promisor affirmatively intended not to perform.

\section{F. TINALEA Clauses}

Our argument about illusory promises turns on an interpretive question: what is it that, in the context in which it is made, a given promise says about the promisor's intent? Accompanied by an express reservation of the right not to perform, a promise does not represent that the promisor intends to perform, though it typically still says that the promisor does not intend not to perform. What about a promise accompanied by a "this is not a legally enforceable agreement" (“TINALEA") clause?

While there are obvious similarities between illusory promises and agreements with TINALEA provisions, we think that they say different things about promisor intent. An illusory promise does not represent a simple intent to perform because it expressly reserves the right not to do so. That is, an illusory promise expressly contemplates nonperformance. This is uot true of a promise with a TINALEA clause. The point of the TINALEA clause is not to reserve the right not to perform, but to shield the promisor against an action for breach. There are any number of reasons why a promisor might want to avoid potential liability for breach of contract besides the fact that she wants to have the right not to perform. Consequently, a TINALEA clause alone

60. Id. But see Blake v. Paramount Pictures, Inc, 22 F. Supp. 249, 253 (S.D. Cal. 1938) (An illusory promise with a liquidated damages clause was essentially a disjunctive promise to perform or pay damages "where the obligation indicates clearly that it contemplates the performance of only one of two acts, [andl in the alternative, no fraud... can exist unless both promises were made without [the] intention to perform."). 
is, in the normal case, not enough to opt out of the default representation of an intent to perform.

Nor should it be enough to opt out of legal liability should that representation be false. While there are persuasive arguments for respecting TINALEA clauses-so that parties can order their actions without fear of suits in contract-these nonenforceable agreements are still on their face meant to induce promisee reliance. And the fact that the parties opted out of contract damages does not mean that they meant also to opt out of this other form of legal liability, which has separate elements and is generally more difficult to establish. Where a promisee has suffered harm as the proximate result of his reasonable reliance on a TINALEA promisor's misrepresented intent, we see no reason not to allow recovery. If the parties want to opt out of damages for promissory fraud, then they should be required to do so separately. ${ }^{61}$

\section{G. Illegal Promises, Promises Against Public Policy, and Defensive Promises}

When a contract contemplates behavior that violates on its face a mandatory substantive rule-for example, when it contemplates a criminal act-there is a stronger rationale for disallowing claims of promissory misrepresentation and fraud, for doing so gives a promisor the ability to bring the substantive violation to light. To take an extreme example, suppose two criminal co-conspirators agree that neither will tell the police they are plotting to kill the President. It would be ludicrous to hold one of the conspirators liable for damages for making such a promise insincerely. Withholding promissory fraud liability in such contexts destabilizes criminal cooperation by helping to ensure there is no honor among thieves. ${ }^{62}$

We can imagine this rationale operating in less dramatic contexts as well-where the agreement is not illegal, but unenforceable as against public policy. Suppose a prospective renter points out that an apartment

61. For example, the agreement, in addition to a TINALEA clause, might say "neither seller nor buyer shall be liable to each other for promissory fraud or any other tort of fraud." For reasons that we discuss in chapter five of Insincere Promises, we would not allow a promisor whose promise is legally enforceable to contract out of all possible liability for promissory fraud. See INSINCERE PROMISES, supra note 8 , ch. 5 . In particular, we would not allow her to opt out of the minimal representation that she does not intend not to perform. Id. But, as we explain in chapter seven of that book, these reasons do not apply where the parties use a TINALEA clause and the promise does not give rise to an action for breach-of-contract. Id. ch. 7 .

62. Keeton comes to the opposite conclusion, based on the doctrinal argument that "[g]enerally, in the law of torts, the plaintiff's conduct does not bar his recovery from a defendant who has been guilty of tortious conduct unless it is of the same general kind, or else of a more serious nature than that of the defendant." Keeton, supra note 9 , at 214 . 
violates certain provisions of the housing code and the landlord offers to reduce the rent if she will sign anyway. This promise may be unenforceable under the mandatory warranty of habitability, which in many jurisdictions allows a tenant to withhold a portion of the rent due until such violations have been corrected. ${ }^{63}$ In this situation, it makes good sense to allow the renter to promise to pay rent and not report the violation, while secretly intending to exercise her legal right not to pay the rent and force the landlord to cure. Waiving the prospect of promissory fraud liability reinforces the mandatory status of the rule, while enforcing promissory fraud would chill the productive effects of whistle-blowing.

A potential application of this reasoning can be found in Galaznik $v$. Galaznik, ${ }^{64}$ in which a Texas Court of Appeals reversed a jury finding of promissory fraud. ${ }^{65}$ The plaintiff had agreed in her divorce settlement not to seek child support from her ex-husband, the defendant, so long as he made payments of three hundred dollars per month - the defendant, an accountant, had insisted on this provision for tax reasons. ${ }^{66}$ A year later, the plaintiff became seriously ill and requested child support. ${ }^{67}$ The jury found that both the plaintiff and the defendant knew at the time the agreement was made that it was unenforceable as against public policy and found that the plaintiff intended to seek modifications when she signed it. ${ }^{68}$

An obvious criticism of the jury's decision is that the plaintiff's illness is a changed circumstance that strongly suggests she changed her mind. However, even if the plaintiff had initially intended to seek modifications, she should not be held liable for promissory fraud. The mandatory rule that agreements not to seek child support are unenforceable is promoted by allowing persons to enter into such an agreement with the intention not to perform. ${ }^{69}$

A harder case presents itself where it is unclear whether the promisee knew about the substantive violation of the mandatory rule. Returning to the landlord-tenant context, imagine that only the prospective tenant-not the landlord-knows of a housing code violation, and that she enters into the lease intending to withhold her 1973)

63. See Boston Hous. Auth. v. Hemingway, 293 N.E.2d 831, 843 (Mass.

64. 685 S.W.2d 379 (Tex. App. 1984).

65. Id. at 385 .

66. Id. at 383

67. Id.

68. Id. at 385

69. The Galaznik court adopted neither of these proposed reasons for reversing the jury verdict. Instead, the court found that the evidence of intent not to perform was insufficient, the ex-husband could not have reasonably relied on the unenforceable promise, and the ex-wife had been taken advantage of in the agreement. Id. 
rent. Enforcing promissory fraud in such asymmetric contexts might induce the tenant instead to disclose the violation to the landlord before contracting. In such cases, promissory fraud liability could work as a beneficial penalty default, forcing the more informed tenant to share what she knows with the landlord before contracting.

But enforcing promissory fraud in asymmetric situations may also leave precontractual whistle-blowers unprotected. The apartment seeker who reveals her sophistication by pointing out that the apartment is not up to code will find it difficult to rent. On balance, it seems that the prospective tenant with private information about a housing code violation should be able to sign the lease without an intent to pay rentthat is, without risking liability for promissory fraud.

The law should take a similar approach with regard to private information an employee has about the employee's legally protected status. Imagine that during a job interview a prospective employer asks whether an applicant's religious beliefs would prevent her from working on Saturdays. Federal regulations governing religious discrimination in the workplace state that such a question violates Title VIl. ${ }^{70}$ The applicant who expects to exercise her right not to work on Saturday for religious reasons should be allowed to misrepresent her intent without incurring liability for promissory fraud..$^{71}$

Another example of an unenforceable contract where no action for promissory fraud should lie is the contract made under duress. When one side to a contract wrongfully tries to extort favorable terms, the other side can make a defensive promise that she intends not to perform without incurring liability for promissory fraud. ${ }^{72}$ The hostage

70. 29 C.F.R. $\$ 1605.3(\mathrm{~b})(2)$. Our example assumes that the employer is subject to these provisions of Title VII (that the job does not fall into one of the exception categories).

71. Thus, the Supreme Judicial Court of Massachusetts was right to hold that a police department could not fire an employee for dishonestly answering in his employment application an illegal question about prior mental hospitalization. Kraft v. Police Comm'r of Boston, 571 N.E.2d 380, 382 (Mass. 1991). Along the same lines, the Americans with Disabilities Act should preempt any attempt to impose liability on a disabled applicant who misrepresented her intent to request accommodations, and the Family Medical Leave Act should preclude liability for an applicant's misrepresentation of her intent to have children.

72. Defensive promissory misrepresentation extends beyond the case of duress. Edith Hamilton summarizes Hercules' visit with Atlas as follows:

Atlas, who bore the vault of heaven upon his shoulders, was the father of Hesperides, so Hercules went to him and asked him to get the [Golden Apples of Hesperides] for him. He offered to take upon himself the burden of the sky while Atlas was away. Atlas, seeing a chance of being relieved forever from his heavy task, gladly agreed. He came back with the apples, but he did not give them to Hercules. He told Hercules he could keep on holding up the sky, for Atlas himself would take the apples to Eurystheus. On this occasion Hercules had only his wits to trust .... He agreed to 
negotiator does not commit a wrong when she insincerely promises the hostage taker that all his demands will be met if he will just let his captives go. The law countenances insincere promising in such a setting-as in all of the above examples of contracts against the public interest-to counteract the wrongful behavior of the promisee.

As an empirical matter, defensive promissory misrepresentation most frequently occurs during attempts to modify existing agreements by threatening breach. A particularly rich source for thinking about promissory fraud liability is the famous case Alaska Packers' Ass'n $v$. Domenico, where there are not one but two possible promissory misrepresentations. ${ }^{73}$ In the first instance, there is the question of whether the fishermen-who shortly after arriving in Alaska collectively stopped work and demanded one hundred dollars each to complete the season-initially intended to perform their promises to work the season for fifty dollars. ${ }^{74}$ The court found that they had refused to continue working "without any valid cause," 75 which might be an indication that, knowing the employer had invested substantial sums in the salmon cannery and would not have recourse to the labor market, they intended from the beginning to extort a higher wage. But this may be attributing too great a degree of knowledge and concerted activity to the fishermen, who might have only hit on the idea after their arrival.

For present purposes, the more interesting issue is whether the Alaska Packers Association spoke sincerely when it capitulated to the employees' wage demand. A promisor acts culpably if she insincerely promises knowing that her promise is not legally enforceable by the operation of the Statute of Frauds or other formal rules. But in this situation we find that two wrongs make a right and valorize the making of a promise that the promisor knows will not be legally enforceable and intends not to perform. We therefore agree with the common law judgment that the victim of extortion, duress, or some other wrongful threat should have the option of making a promise that she intends not to perform. Of course this rule will only work against extortionists who are unaware of the rule itself. More savvy fishermen will know that the modified contract is not worth the paper it is written on and will demand to be paid the extra money in advance.

Atlas' plan, but asked him to take the sky back for just a moment so that Hercules could put a pad on his shoulders to ease the pressure. Atlas did so, and Hercules picked up the apples and went off.

HAMILTON, supra note 5, at 233 . Notice the structural similarity to our proposed reading of Alaska Packers' Association v. Domenico, 117 F. 99 (9th Cir. 1902). See discussion infra notes 73-75 and accompanying text.

73. See 117 F. at 101-02.

74. Id. at 100 .

75. Id. at 102 . 


\section{H. Procreative and Political Promises}

All of the situations in the preceding section share a basic rationale for suspending promissory fraud liability: to allow promisors to use promissory misrepresentations to prevent harms by bad promisees. This rationale does not apply to all agreements unenforceable for reasons of public policy. There is a category of transactions where the agreement itself does not implicate public policy concerns or violate substantive rules, but its legal enforcement would be problematic. For instance, a variety of procreative agreements are socially unobjectionable but legally unenforceable. ${ }^{76}$ These unenforceable agreements present a more difficult policy question, because the whistle-blower rationale for waiving promissory fraud liability is not present and the promisee may be a real victim.

Imagine for example that a woman promises her sexual partner that she will abort, or not abort, if she gets pregnant and that this promise is a condition of her partner's participation. It is clear that the promise will not be specifically enforced, and almost as clear that the breach itself will not create monetary liability. But what if the promisee can also prove that the promisor initially intended not to perform her promise? Should she be liable not for the breach, but for her promissory misrepresentation?

According to the theory wc have developed, the promisor has acted wrongly. But there is the countervailing fear that imposing legal liability for her misrepresentation will indirectly influence the promisor's ex post procreative choice, which is the reason the promise is unenforceable in the first place. ${ }^{77}$ We do not want to burden a woman's choice whether or not to have a child by potential liability for promissory fraud or even negligent promissory misrepresentation.

Election promises exhibit roughly the same characteristic and clearly they are not enforceable. But what if the promise is made insincerely? When Vice President George Bush said "read my lips: no new taxes," did he misrepresent his present intent, knowing that the fiscal situation might well require new taxes, or did an unexpccted downturn in the economy cause him to change his intentions? And if he

76. The exception has traditionally been procreative agreements that are part of a marriage commitment, where promissory insincerity was often grounds for annulment or divorce. See generally T.C. Williams, Avoidance of Procreation of Children as Ground for Divorce or Annulment of Marriage, 4 A.L.R.2D 227 (1949). Such promises are, apparently, increasingly common in prenuptial agreements. See Jill Brooke, $A$ Promise to Love, Honor and Bear No Children, N.Y. Times, Oct. 13, 2002, §9, at 1.

77. See generally Jennifer Gerarda Brown, The "Sophie's Choice" Paradox and the Discontinuous Self: Two Comments on Wertheimer, 74 DENV. U. L. REV. 1255 (1997). 
did misrepresent his intent, why should he not be held liable for that wrongful act? ${ }^{78}$

There are two aspects of these promises that together create the dilemma. One is the importance we attach to the ex post choice whether or not to perform. These are areas where we want actors to be able to make independent choices based on their own best interest or judgment-not on legal consequences. ${ }^{79}$ Second, there is a significant delay between the promise and the time of performance, meaning that the promisor is more likely to have a change of heart. Thus a promise to use, or not to use, contraceptives is less likely to raise issues of subsequent choice than a promise to abort, and more likely to be the proper basis for liability if there were a promissory misrepresentation.

Practical complexities, however, preclude easy answers. Thus in Wallis $v$. Smith, ${ }^{80}$ a New Mexico Court of Appeals rejected a contraceptive fraud claim. The court of appeals held that the claimant failed to state claim even though the defendant had chosen to stop avoiding pregnancy, intentionally misrepresented to the claimant that she was using birth control, and thereby misled the claimant into having sex. ${ }^{81}$ The court of appeal's decision may have been motivated by the fact that the father was suing for reimbursement of his child-support obligation. ${ }^{82}$ But while it is sound social policy to assure that child support is paid, there is a strong argument that when the mother has sufficient funds and has defrauded the father, the latter should be able to shift the burden of child support to her. There is in this situation no ex post choice to protect. But we are aware of no court that has entertained even the possibility of promissory fraud liability in such

78. See generally Stephen D. Sencer, Read My Lips: Examining the Legal Implications of Knowingly False Campaign Promises, 90 MiCH. L. Rev. 428 (1991). Stephen Sencer takes the position that liability for insincere campaign promises would be a good thing, and that the only problem is crafting a workable damages regime. Id. at 431. To reach this conclusion, however, Sencer has to adopt a fairly extreme version of the mandate theory of representation, according to which elected representatives should serve only as conduits for the will of the people, rather than as trustees required to exercise their independent judgment. See, e.g., Hanna F. PITKIN, THE CONCEPT OF REPRESENTATION 146-47 (1967). Thus, Sencer argues that if we could solve the damages problem, then all campaign promises-whether sincere or not-should, if broken, give rise even to breach-of-contract liability. Sencer, supra, at 445-57. But Sencer does not address the problem of the electorate's changing will. There is no clear mechanism for releasing a politician from a campaign promise should the will of the people change. Consequently, even under the mandate theory, campaign promises may not be the best transmission mechanism and liability, be it in contract or in tort, may not be appropriate.

79. Think also about the decision to donate an organ, to serve as a surrogate mother, or, some would say, to end one's life if terminally ill.

80. 22 P.3d 682 (N.M. Ct. App. 2001).

81. Id. at 685 .

82. Id. at 683-84. 
circumstances. $^{83}$ And while promissory fraud liability looks good in theory, these cases may well reflect a completely correct recognition of social reality-including a common lack of perfect consent in sexual relations and economic imbalances.

One way to prevent the burden on a woman's or elected official's ex post choice would be to allow the action for promissory fraud even in the absence of nonperformance. ${ }^{84}$ Nonperformance is generally an element of promissory fraud, because proximate cause is an element of deceit and the proximate harms of a promissory misrepresentation are just those caused by the promisor's nonperformance. But in cases where we are especially worried about protecting the ex post choice not to perform, we could decouple performance from promissory fraud liability, in which case the promisor would not escape liability by changing her mind and performing. Indeed, the rule might be that in certain cases the fact of nonperformance is inadmissible, so that the lack of intent or the intent not to perform must be established solely on the basis of other evidence.

While this possibility is interesting in theory, we doubt that it would function in practice. Performance is so likely to prevent any action for promissory fraud that maintaining ex post freedom of choice requires that we simply exempt procreative and political promises from potential promissory fraud liability. These difficult, real-world questions are an apt place to end our survey of the manifold ways that promissory fraud can arise in the absence of enforceable contracts.

\section{CONCLUSION}

Promissory fraud is not a doctrine where tort principles just happen to overlap with contractual behavior. Rather, legal liability for insincere promising has a well-defined function within the apparatus of the law of contracts. It promotes the credible transfer of information about the promisor's intentions. Such information can tell a promisee whether it is in his interest to enter into the contract, with whom he should contract, and how much he should invest in reliance. But this

83. See Erwin L.D. v. Myla Jean L., 847 S.W.2d 45, 47 (Ark. App. 1993); Henson v. Sorrell, No. 02A01-9711-CV-00291, 1999 WL 5630, at*3 (Tenn. Ct. App.); Melanie G. McCulley, The Male Abortion: The Putative Father's Right to Terminate His Interests in and Obligations to the Unborn Child, 7 J.L. \& POL'Y 1, 23 (1998).

84. Another possibility in the context of political promises, which Sencer suggests, would be to limit the plaintiff's relief to a declaratory judgment that the candidate's promise was insincere. Sencer, supra note 78 , at 468 . Since politicians are particularly sensitive to reputational sanctions, this sanction might provide some desirable ex ante deterrence without unduly constraining the ex post choice. Id. While we doubt that the judiciary, at least in this country, would feel comfortable reaching sucl judgments, this might be an appropriate action for an independent election commission. 
does not mean that liability for promissory fraud should track or be conditioned on contractual liability. Whether or not there should be liability for promissory fraud depends on the reason for excusing the promisor from liability for breach.

In some contexts, the question turns on the correct interpretation of just what the promise said about the promisor's intent. Thus, if a statement is mere puff, then it says nothing about the promisor's intentions with respect to performance and should not give rise to an action for promissory fraud, even if, when she made her promise-like statement, she intended not to perform. At the other end of the spectrum, a promise with a TINALEA clause is still a promise and still represents an intent to perform. As such, it should give rise to liability for promissory fraud if the promisor does not intend to perform. Between these two extremes are promises that do not say that the promisor intends to perform, but do represent that she does not intend not to do so. Thus, option contracts, precontractual representations, and illusory promises can all be the basis of an action for promissory fraud even where there is no action for breach. In these situations, however, a plaintiff's burden is higher. He must prove not only that the promisor did not intend to perform, but that she affirmatively intended not to.

When it comes to other sorts of unenforceable promises, whether promissory fraud liability is appropriate depends on the rationale for unenforceability. Where a promise will not be enforced because of some formal defect-like noncompliance with the Statute of Frauds or the consideration requirement-an action for promissory fraud should not be ruled out. In fact, permitting promissory fraud liability prevents bad promisors from using these antifraud mechanisms as tools for fraud. Promissory fraud liability is not appropriate, however, in agreements that are unenforceable because they violate some substantive norm, for example, because they contemplate something illegal, are against public policy, or result from duress or other bad actions in the formation. By waiving promissory fraud liability in these cases, we can undermine honor among thieves and encourage whistle-blowers. Finally, we should probably also withdraw promissory fraud liability where an agreement is unenforceable not because of its substance, but because legal enforcement itself is problematic. Thus, in the case of political and procreative promises where we have a strong interest in protecting promisors' ex post choice not to perform, there should be no liability for an initial intent not to do so. 
HeinOnline -- 2004 Wis. L. Rev. 5342004 